\title{
PROBLEMATISING THE DEVELOPMENT OF SAME-SEX RHETORIC IN SELECTED REFORMED DENOMINATIONAL TRADITIONS IN SOUTH AFRICA
}

\author{
Johannes N Vorster \\ Department of New Testament and Early Christian Studies \\ University of South Africa
}

\begin{abstract}
If same-sex discourse is part of regulatory practices that both produce and control bodies, its development in the Dutch Reformed Church requires a genealogical enquiry into the discursive practices from which it has emerged. It is argued that the same-sex discourse which has developed within the Dutch Reformed Church serves to protect heteronormativity and biblical discourse, and integrated within regulatory practice, is instrumental in its accomplishment.
\end{abstract}

Keywords: Foucaultian Approach, Homosexuality, Homosexuality and Biblical Discourse, Same-sex Rhetoric, Dutch Reformed Church and Homosexuality

\section{Introduction: Is a Conversation still Possible?}

The South African Constitution provides for freedom of religion, belief and opinion 15(1) and this freedom is only constrained where it contradicts the spirit of the Constitution. However, if we take the type of body rhetoric prevailing within religious discourses into consideration, is it possible to allow for the freedom of religion? Hate speech may have been outlawed, but does the Constitution not perpetuate and protect principles which have generated hate speech? If we allow for a discourse protecting religious rights, can we simultaneously allow for a discourse, protecting individual rights and bodily integrity? When religions invest in the construction of hierarchies between people, whether between those 'inside' and those 'outside' or between 'man' and 'woman' or between 'man' and 'man' and reflect these hierarchies in their construction of their pantheon, why should it be granted a constitutional right to flourish? When a court of law decides that a church leadership must apologise for firing one of its own officials on the basis of same-sex desire but there appears to be no real moral concern from the church leadership or its members, does it not signify a rather ridiculous co-existence of two incompatible discourses? When a moderator resigns his office out of desperation to lead a denomination away from sexually discriminatory practices, despite the proud tradition of this denomination against colourbased discriminatory practices, what are the possibilities for a deliberation enabling the development of a collective political will, what are the possibilities for a democratisation where the consensual is constantly kept in check by the dissenting?

To be fair, there is a wide variety of religious discourses and they do not all operate from a unilateral motivation for power. Furthermore, conversations, discussions, study groups, seminars and a host of enquiring practices, challenging totalitarian modes of interaction, have gradually evolved in many religious groups, albeit not always prompted from within, but from outside forces. And yet if we take the rhetorics of the body, as they developed in what has become known as the 'gay-debate,' a patriarchal, hierarchical rigidity is seriously hampering processes of an emergent democracy. Again, not all church- 
going people participate in this ethos, but despite of deliberate delayals in decision-making processes, hosts of enquiring committees or task teams, extensive reports, seminars and conferences, the highest (in their own terms 'broadest') official bodies time and again appear to opt for a rhetoric of the body promoting an engendered hierarchy, consisting of some people more equal than others.

An easy solution does not exist, but if there is to be progression, if there is to be cooperation and identification, we need to ask how rhetoric is possible in a situation where apparently conflicting discourses are required to co-exist. What are the possibilities of rhetoric where apparently incompatible discursive regimes are at work? Conflict, strife, division and dissent, just as the desire for cooperation, consensus, and identification are not strange to rhetoric, since these are exactly the prompters inviting rhetoric (Burke 1969:25). If we may define rhetoric's objective as the construction of discourses which can keep conversations going, which can allow for a mode of persuasion with greater or lesser force in the context of civil address, how does one keep the conversation going when the language of address, the conversational strategies, the conditions for making the conversation work, differ to such an extent as to render conversation practically impossible?

Peters \& Rothenbuhler (1989) write that democratisation means to provide access for all to the construction of reality. A construction is only worthy the status of reality if all were able to participate in the construction thereof. For that reason participation becomes the criterion for what democratisation entails. Where participation does not succeed, totalitarianism sets in as all parties are subjected to the construction of a particular reality, and the possibilities of rhetoric are restricted to that of coercion and violence. However, it could be argued that gay persons are not denied membership of the churches and that in the enquiries concerning 'homosexuality' gays were indeed invited to participate in the discussions. Is participation sufficient? Is participation really the concern? What exactly does participation entail?

The problem is not participation, but the discursive conditions and practices prompting and allowing for participation. At stake is a complex conflict between discourses, not easily classified as 'dominant' versus 'marginalised.' ${ }^{1}$ What if the legacy of a discursive regime acquired such power that it has virtually become impossible to deliberate and deliberation takes place only by dictating the rules of the game? Why participate when the rules of participation have already been given factual status? To what extent is the recognition of the so-called 'other' determined by such rigid regulatory norms as to render the 'other' unrecognisable? What if a discursive regime has acquired such power that it may inhibit and even destroy the conditions for the formation of an ethical subject? What if the power of a discursive regime obstructs and obfuscates the conditions enabling not only the recognition of the 'self,' but also the capacity of the 'self' for self-recognition and selfformation? How does it become possible where ethical violence is quite clearly the norm? Religious rhetoric often effectively removes the possibility of deliberation by an appeal to an authoritative 'voice,' claiming a particular interpretation as superior by taking recourse

\footnotetext{
Discourse is here used in the Foucaultian sense, referring not only to coherent, cohesive groups of statements, but also to those practices and mechanisms that have produced them. Furthermore, there is a constant interaction between discourse and power; discourse can be seen as the product of power relations, but at the same time it functions to reinforce or resist power. In every society or community production of discourse is controlled in several ways, it is protected by particular mechanisms and practices are called into existence to defend against the onslaught of other discourses. One way of ensuring its dominance and permanency is its institutionalisation which allows for a whole array of practices and mechanisms, both to protect and defend (for a concise, summarised explanation of Foucault's views on discourse, power and knowledge see Mills 2003, 53-79).
} 
either to an untouchable notion such as 'faith' or 'belief' or to an untouchable past, evoking particular traditional interpretations. A mysterious world beyond that of civil society is called upon to decide the outcome of argumentation and a claim of privileged access to this world removes the possibility of deliberation and informed decision-making. The effect is a move to the 'inside' of the group; instead of a public debate, group consolidation takes place, and a discursive edifice with an unshifting foundation, impenetrable walls, uniform enclosing spaces and mechanisms of surveillance are erected, to keep 'insiders' in and 'outsiders' out. The interaction with the 'outside world' can only be that of hostility and alienation.

In this article the emerging same-sex discourse within the reformed tradition in South Africa is problematised to gain some perspective on the mechanisms and processes of power that have operated in its production. In particular attention is paid to the type of rhetoric at work in the integration of biblical discourse in institutionalised denominational practices, regulating same-sex relations. The underlying question is what, or maybe whether, rhetoric is possible once a perspective has been gained on how denominational, institutionalised discourse functions to protect itself. My focus is particularly on the development of same-sex discourse within the Dutch Reformed Church (hereafter DRC). Although a variety of religious communities have been involved in the so-called 'gaydebate,' it has been the DRC which has taken the lead and which has produced the more extensive work on the subject. The work this denomination has produced over more than a decade forms the basis of my enquiry, but it is not restricted to their material only. Enquiries which have been launched by other denominations have also been included. Furthermore, in an attempt to understand the rhetorical mechanisms behind the official policies and statements, not only officially mandated studies by task teams have been taken into consideration, but also letters to the press, articles and letters in church magazines, and press releases have been scrutinised. What has unfolded before my eyes was amazing to the extent that it confirmed exactly Foucault's position on the proliferation of discursive material during the end of the eighteenth, beginning of the nineteenth century in Europe. A regime for the 'policing of sex' has emerged, not policing through the rigidity of a taboo, but the necessity of regulating sex through useful and public discourses (1978:25). Masking its own thirst for power, a unique denominational scientia sexualis was produced, publicly motivated by the leadership's desire to make a wise and informed decision. The scope of an article does not provide for a detailed analysis, but it offers the possibility of problematising at least some of the discursive practices produced by and producing the gay-debate.

\section{The Development of Same-Sex Rhetoric in the DRC}

If we wish to consider the way in which the DRC regulated discourse concerning gays, it would be possible to structure it according to three significant events, namely the General Synods of 1986, 2002 and 2007. Although the period, immediately following the General Synod of 2004, can be characterised as one of upheaval, confusion and a specific focus on gay-marriages, no significant changes have taken place as far as the decisions of the church were concerned.

Prior to the arrival of the South African Constitution with its Bill of Rights (chapter 2) in 1997 very little evidence can be provided of what has become a 'gay-problem' within this denomination. ${ }^{2}$ To be 'gay' was to be exiled to the taboo-world of the unthinkable and

See Nederduits Gereformeerde Kerk, Agenda van die Algemene Sinode 2002, 246-254 at 14.1.2. (Pretoria: Nederduitse Gereformeerde Kerk), ABID, 1. Cited 30 July 2008. E-mail: ngkinlig@mweb.co.za 
unmentionable. One of the decisions taken during a 1986 General Synod of the DRC submitted that homosexuality is a sin, a form of deviant sexuality and against the will of God. ${ }^{3}$ In 1986 the discursive system of this denomination on sexuality was protected by a very clear-cut position. Church leadership at that stage, knew that there was a condition such as 'homosexuality,' they knew that Scriptures offered a perspective on 'homosexuality,' they knew what Scriptures had to say on this condition, and they knew that the perspective of Scriptures was negative. In addition they even knew what the will of God was and they knew what attitude to adopt in response. What counted as knowledge concerning sexuality was completely heteronormative with a certainty about the deviancy of same-sex conditions. This was the default situation up to 1986. Normative discourse within the previous regime simply outlawed same-sex desire from public consciousness and were it not for a South African Constitution with a Bill of Rights, it would probably have remained that way. ${ }^{4}$ Owing to the size of the Dutch Reformed Church, which is also the biggest mainstream Afrikaner religious community, it is difficult to exactly determine an event or date for the beginning of this debate. What appears to be more certain is that the initial phases of this debate can be located in synchrony with the development of thinking around the Constitution. The 1995 Synod of the Western and Southern Cape instructed its Committee for Doctrine and Contemporary Issues, to submit a report which they duly did in 1999, entitled "Pastoral Guidance to the Homosexual Person" (my translation). ${ }^{5}$ Although this report was not intended as forcing a particular decision on the Synod of the Western and Southern Cape, it elicited a flood of letters in the church's official journal, Die Kerkbode. ${ }^{6}$ The approaching legislation, such as the Act on the Prevention of Unfair

3 In an almost tautological sense it is condemned in two clauses: "Homosexuality is in light of the Scriptures a deviant form of sexuality" (my translation), and then again: "Homosexual practices and a homosexual relationship must be declined as in conflict with the will of God as revealed in the Holy Scriptures" (my translation) (Nederduitse Gereformeerde Kerk, Besluite van die Algemene Sinode 1986, 363 at 5.1, 2).

4 The reports compiled by the Task Team of the General Synod of the Dutch Reformed Church (2007) give the impression that the church paid attention to same-sex relationships owing to the emergence and legitimation of homosexuality as a worldwide ecumenical issue. This is only partially true, since there is a clear escalation in articles, discussion forums and correspondence in official denominational journals, firstly with the advent of a South African Bill of Rights, and secondly when the issue of gay-marriages was looming on the horizon. To the credit of the church-going public there is a clear correspondence between an increased awareness for equal rights prompted by the Bill of Rights and a sensitivity for the rights of gay persons (Nederduitse Gereformeerde Kerk, Agenda Deel I: Dokumentebundel vir die 13de Vergadering van die Algemene Sinode van die Nederduitse Gereformeerde Kerk, Boksburg 4-7 Junie 2007. Verslag van die Taakspan:

Homoseksualiteit, 145 - bylaag 1, 1, also 164, bylaag 2, 1.1 and 171, bylaag 2, 2.1.

5 The objective of this report, which was mandated in 1995, quite balanced and sympathetic, was nonetheless pastoral. How homosexuality was here regarded as a condition in need of 'pastoral guidance,' a condition which must be remedied, should not be overlooked (see Nederduitse Gereformeerde Kerk, Agenda 1999: Bylae A13-1 van die Verslag van die Kommissie vir Leer en Aktuele Sake van Wes- en Suid-Kaap Sinode. Pastoraat aan die homoseksuele persoon. (Pretoria: Nederduitse Gereformeerde Kerk, 1999).

6 See for example: Lidmate verskil skerp oor homo-verslag, September 1999. Die Kerkbode 163(6), front page; Wessels, F 1999 (September). Vet in vuur oor homoseksualiteit, Die Kerkbode 163(7), 8; Wes-Tvl verander besluit oor homoseksualiteit, 1999 (September). Die Kerkbode 163(8), 2; Luyt, C 1999 (October). Nie weer na te dink oor homoseks, Die Kerkbode 163(9), 7; Kloppers, BJ 1999 (November). Homo's laat gesin uit NG Kerk loop, Die Kerkbode 163(11), 9; De Villiers, E 1999 (November). 'Prosedure' pootjie debat oor homo's, Die Kerkbode 163(11), 9; Die Kerkraad, 1999 (November). Wat sê die Here oor homoseksualiteit, Die Kerkbode 163(13), 5; Botha, A 1999 (November). Gemeentes wil oor gays praat, Die Kerkbode 163(13), 5; Benadé, L 1999 (December). Gay-wees nie ál wat Bybel verbied, Die Kerkbode 163(16), 7; see also, for example, the response on the Declaration of Faith 2000, 1999 (July). Die Kerkbode 163, no. 7, in which the $15^{\text {th }}$ declaration briefly touched on homosexuality; Janse van Rensburg, R 1999 (September). Wat God van homoseksualiteit dink... Die Kerkbode 163(8), 8; Viljoen, WJ 1999 (September). Homo's misbruik hulle seksualiteit, Die Kerkbode 163(8), 8. 
Discrimination, and the (at that stage looming) Civil Union Bill simultaneously contributed to put same-sex relations into public discourse, thereby enacting counter regulatory procedures. $^{7}$ The period since 1986 can be characterised by an increasing proliferation of discursive practices concerning same-sex relations. Same-sex relationships were given a public presence via study groups, task committees, seminars, conferences, official meetings, and widespread public correspondence. Each of these practices can be seen as a reiterated speech act that is power enacted, allowing for the development of a rhetoric which was to ensure and protect the continuity of dominant denominational discourse.

And yet, it was at the General Synod of 2002 that the decision of the 1986 Synod was revoked. ${ }^{8}$ No decision was taken except that the Synod can no longer abide by its 1986 decision. The 'light of Scriptures' that shone so clearly, has apparently significantly dimmed! The decision was, however, interpreted to imply that an open situation has dawned in anticipation of what would happen at the next General Synod; furthermore, that a comprehensive study concerning homosexuality should be done, that the church acknowledges and apologises for wrongdoing concerning gay members and that gays were welcomed in local congregations. The decision was also interpreted not to imply that a marriage could be anything but a union between one man and one woman according to Scriptures. ${ }^{9}$ It would not be too far off the mark to see 2002 within this denomination as the year for the official problematisation of gay identity. ${ }^{10}$ The default dominant discourse of which the 1986 decision was an expression, was for the first time critically questioned in public. This, however, did not mean an abolishment of what was made into a problem, but it was to set the scene for the development of discourse which would regulate same-sex in a manner so as to protect and ensure the continuity of the system. From 2002 the 'gay problem' remained on every synod including the General Synod's agenda and although no decisions were taken, committees of inquiry were mandated to investigate what constituted the 'gay problem.'

In 2004 homosexuality was again on the agenda of the General Synod, but as predicted by some, ${ }^{11}$ no decision was taken and apparently the status quo remained virtually the same when only the decisions of the General Synod are taken into consideration. ${ }^{12}$ However, if

See for example the opinions of Danie du Toit, Kobus van Rooyen and Kenneth Meshoe in Gay-huwelike mag nié, 2001 (February), Die Kerkbode 164(1), 1 by this time refuted by reality, and in Wet op Gelykheid "Bied nie agterdeur vir Gay-huwelike," 2000 (April), Die Kerkbode 164(3), 2, the opinions of Kobus van Rooyen (again) and Carl Lemhkuhl, by this time also refuted by reality; also De Swardt, AJ 2000 (March). Gay huwelike te skandelik om te noem, Die Kerkbode 164(2), 13.

$8 \quad$ See Nederduits Gereformeerde Kerk, Agenda, Notule en Besluiteregister van die Algemene Sinode 2002, (Pretoria: Nederduitse Gereformeerde Kerk, 2002; ABID: ngkinlig@mweb.co.za), 246-254, at 14.1.2; 14.11.1 and also 554 at 14.1 of the Minutes; of the Register of Decisions, 624 at 12.1 . However at the same time the Orange Free State's Synod's point for discussion which explicitly establishes a continuity with the 1986 Synod's view on homosexuality as against Scriptures is referred to the Committee tasked to make a study of homosexuality; see Nederduitse Gereformeerde Kerk, Algemene Sinode 2002, Beskrywingspunt van OVS Sinode, 436-439 and Notule, 504.

9 See Nederduitse Gereformeerde Kerk, Die elfde Algemene Sinode - 2004. D. Inhoudelike Notule: 14. Homoseksualiteit, 1-6 (Pretoria: Nederduitse Gereformeerde Kerk, 2004; ABID: ngkinlig@mweb.co.za), 39.

10 'Problematisation' should here be seen in a Foucaultian sense. Although the official decisions kept the issue in suspense, the document which formed part of the General Synod's agenda clearly questioned dominant discourse's perspective.

11 See "Gay-verslag sal nie finale antwoorde hê", Die Kerkbode (11/06/04), n.p. [cited 25 November 2008]. Online:http:// Op Die Rand Van Die Beloofde Land, Die Kerkbode (22/10/04) n.p. [cited 25 November 2008]. Online: http://kerkbode.co.za/kerkbode/berig.asp?id=315

12 See in this respect, Nederduitse Gereformeerde Kerk, Algemene Sinode-2004. F.1.9 Besluiteregister: 3.Homoseksualiteit, 3.1-3.7 (Pretoria: Nederduitse Gereformeerde Kerk, 2004: ABID: E-mail: ngkinlig@mweb.co.za), 433. 
the recommendations of the enquiring Committee are taken into consideration, subtle, but significant shifts have appeared. Whereas the 2002 recommendations report could be characterised by excessive theologising, criss-crossed by dogmatic and ethical jargon, and introducing irrelevant distinctions, ${ }^{13}$ all in an attempt to understand the 'problem' of homosexuality, the 2004 recommendations have shifted its focus to the ministry of the church. Not only was the rhetorical objective to remove prejudice against gay persons, but the discourse consistently reflects two main opposing parties within the church. Its most significant feature is, however, the shift from the 'problem' of homosexuality to the 'problem' of the churchgoing people (including their leadership) entrenching themselves in two opposing trenches on the issue of homosexuality. The focus has now become the rhetorical mode in which the discourse or deliberation on homosexuality should be constructed (see 4.7) as can also be seen by the deliberate attempt to seek a 'meeting of minds' via an appeal to attitude (4.7.1), to an emphasis on similarities, but also on existing diversities. ${ }^{14}$ The question has shifted to how discourse concerning gays is to be regulated.

Gay discourse is regulated by evoking a conversational scenario, in which the church is prompted by the task committee on 'homosexuality' to adopt the passive position of the 'listener'. Three oracular sites are proposed: firstly, the Bible, which can be seen as an evocation of the canonical principle; secondly, 'non-theological factors' which refer to the disciplinary principle and thirdly, those who have actual experience of homosexual conditions whether directly or indirectly, which can be seen as an expression of the confessional principle. At first sight these three sites apparently function as informative sources concerning the gay debate. However, the adoption of a 'listening' position should be seen as extremely metaphoric, because what is at stake is a regulation of the interpretative act. The 'taking seriously of the Bible' should happen within the constraints of reformed readings of the Bible, of which the consolidating feature is the acknowledgement of its authority. The act of 'listening' must therefore take place within the already given confinements of reformed tradition. For that reason a distinction can also be made between 'responsible' exegesis and theology and the implied 'irresponsible' which obviously requires no attention, a 'responsible' hermeneutics and an implied 'iresponsible' hermemeneutics as framework for understanding. By evoking the disciplinary principle, knowledge generated by the experts, those in the field of the 'bio-psychosocial' are regulated by its integration into the knowledge production of the DRC. However, the knowledge integrated must again be constrained by 'insider' interest. ${ }^{15}$ The consensus thus effected can be characterised as 'responsible,' based on 'reliable knowledge' that is not contaminated by contextual contingencies. In the final instance expression is given to the confessional principle, allowing for all interested parties to join the 'conversation'. However, the knowledge gained by this open approach, which indeed allows for the participation of gay persons, is to be regarded as non-normative. And yet, the confessional mode of knowledge acquisition puts the confessor in the vulnerable position of

13 See for example the rather outdated and absurd biblically inspired intepretative principle making a distinction between the spirit and the letter (Nederduitse Gereformeerde Kerk, Algemene Sinode - 2002. Agenda at 14.2.7) in an attempt to move its readership to understand the (S)spirit in the letter ("die (G)gees in die letter"). This forms a recurring theme throughout the document (see $14.3 .2 ; 3.3 ; 4.3 ; 4.4 ; 6.4 ; 7.5$ ); the same applies to the distinction between 'torah' and 'nomos' (14.4) and between 'sexus,' 'eros,' 'philia,' and 'agapè' (14.9.2-6), in Nederduitse Gereformeerde Kerk, Algemene Sinode - 2002. Agenda: 14. Homoseksualiteit at 14.1-11.

14 See Nederduitse Gereformeerde Kerk, Algemene Sinode-2004. Agenda 138-151 at 4.7.

15 The sources selected and used within the disciplinary field must promote "meaningful and informed conversation in the church" (sinvolle en ingeligte gesprek in die kerk - italics mine) and should not be detrimental to this insider conversation (see Nederduitse Gereformeerde Kerk, Algemene Sinode - 2004 Agenda at 4.7.2.2.*2). 
submission - no outcome is guaranteed, no promise is made, but the listener occupies the position of 'judge.' Knowledge produced by the interpretative act is therefore regulated according to a strict normative hierarchy fencing in what may count as knowledge within reformed tradition, but excluding what is not in continuity with this tradition.

Despite of the acknowledgement of multiple interpretational possibilites, an interpretation, rendering marriage as an institutional rite not only restricted to a man and a woman, is excluded. As a matter of fact, just as in 2002 the canonical principle functioned as mechanism to confirm the heteronormativity of marriage, thereby regulating the exclusion of same-sex partners from a discursive practice of immense social power. In the period 2004 to 2007 the appeal to the canonical principle regulating the exclusion of samesex couples from the institution of marriage would be constantly implemented, despite of the DRC's acknowledgement of multiple interpretational possibilities and despite of the accumulative production of discourse concerned with same-sex problematisation.

Same-sex discourse generated during the period 2004 to 2007 centred around two issues, namely gay marriages within the context of an emerging Civil Union Bill and access of gays to the office of minister, that is, access to the power structures of the institution. These two issues are not unrelated. Excluding gays from marriage, compels them into the realm of 'taboo' - into the possibility of extra-marital sex, if they were to engage in a samesex relationship... and this implies an inappropriate lifestyle for a minister. There is also another level of relatedness. Both the issues of gay marriages and access to church hierarchy concern institutional space. The same-sex discourse produced during this period was concerned with the regulation of institutional space; in the case of gay marriages the institution of marriage was at stake, and although partially belonging to the private sphere, marriage has always been an institutional locus for the regulation of social order whichever order may at that stage be the order of the day. On the one hand, it serves to reflect the social order of its day, but on the other hand, embedded in a variety of power relations it also serves to produce a particular order. With a Bill of Rights of which the regulatory impulses have shifted away from marriage as a site for the regulation of desire, various possibilities have opened. The church, however, was in a dilemma because marriage as a mechanism for social control has always been part of denominational strategy to ensure its continued existence. The nuclear family functions as a relay between past, present and future - as the site for the incorporation of traditions, it also functions formatively with a view to the future. Ensuring marriage between a 'man' and a 'woman' with the possibility of reproduction is an almost unnegotiable strategy for its future survival. It was therefore fairly clear from 2004 that despite of a host of practices producing same-sex discourse, regulatory practice excluding gays from both the institution of marriage and access to church hierarchy would have won the day, irrespective of the noble intentions of many individuals involved in the project to emancipate reformed tradition.

From 2004 the battle to ensure the domination and continuation of heteronormative discourse in both the institutions of marriage and church hierarchy intensified. This was partly due to increasing pressure from the judiciary on the legislative to get rid of the 1961 Marriage Act and introduce a Civil Union Bill aligning with the Bill of Rights. ${ }^{16}$

16 See for example the case of Fourie and Bonthuys (30 November 2004) in which the Appeal Court ruled in their favour and which also led the Constitutional Court to request the state to revise marriage legislation after allowing hearings from groups with vested interests. On 1 December 2004 the DRC via its General Secretary issued a press release reiterating the church's position on marriage as a union between one man and one woman (see Gerber, K 2004. Nederduitse Gereformeerde Kerk, Mediavrystelling: Hofuitspraak oor Gay Huwelike. Online: http://www.ngkerk.org.za/Hofuitspraak\%20Gay-huwelike\%Pers.htm 
Heteronormative discourse, on the other hand, was not only dominant among denominational public, but despite of several resisting voices, it was also still strongly represented in the hierarchies of the church. For that reason, the decision made by the General Synod in 2002 and repeated in 2004 regulating marital relationship had to be repeatedly cited in order to assure continuity with the reformed tradition and to ward off discourse which may pose a threat to this continuity ... and each time it was cited, it was the power of heteronormativity enacted. ${ }^{17}$ In the official response to the Civil Unions Bill, heteronormative discourse was again enacted when it is explained to the Committee that the reformed tradition views marriage as a union between one man and one woman as unnegotiable. Although recognition is given to social changes rendering alternative forms of family life, the nuclear family with the possibility of reproduction is related to peace, stability, progression and the establishment of healthy values. The deepseated differences of opinion regarding regarding the mode of union between same-sex couples were reflected, rendering this an area of negotiability. Although discrimination against same-sex relations is condemned, the DRC requested that marriage remains a site of heteronormative control. The objective was clearly to establish heteronormative immunity for 'marriage' while allowing some kind of union next to it. ${ }^{18}$ Despite of its attempt to protect the heteronormativity of Christian marriage, the presentation's publication created such a furore in the DRC that its continuity with reformed tradition had to be defended and its credibility as dominant discourse had to be established in two press releases. ${ }^{19}$

It comes as no surprise that the General Synod of 2007 ended up with two reports presented by the Task Team on Homosexuality, of which the first presented as Bylaag 1 (Addendum 1), reflects a more enlightened position. However, it is explicitly stated that it would still be more acceptable if marriage is defined in 'heterosexual terms' and that a new institution iuxtaposed to marriage be created for gay couples. ${ }^{20}$ The eventual decisions taken by General Synod demonstrate to what extent heteronormative discourse succeeded in

17 The decision reads: "According to our understanding of Scriptures only the union between one man and one woman can be seen as marriage" (my translation, see Nederduitse Gereformeerde Kerk, Algemene Sinode 2002. Besluiteregister 624 at 12.11.2 and Nederduitse Gereformeerde Kerk, Algemene Sinode - 2004. Inhoudelike Notule 374, at 4.10.5 and 433, F.1.9.3.3.5).

18 The intended impression was obviously to simulate equal status for such a union and this was also explicitly stated. However, the stylistics suggested rather a mode of discourse protecting heteronormativity as basis for what is called marriage. This can be seen in the reference to its unnegotiability, while the position of same-sex relations are seen as highly negotiable (stability, familiarity versus instability, infamiliarity), marriage is qualified as 'healthy' and contributing to 'healthy values' rendering a site where positive civil values can be taught; whereas the reformed tradition would experience any alternative to a heterosexual marriage as a 'threat,' gays are not even sure themselves whether they would opt for what is known as 'marriage.' In suggesting a way forward, a proposal for one umbrella law is made which would render equal status to all 'similar unions' in other cultures and religions. When these are referred to (Jews, Muslims, Hindus, Buddhists, African religions), same-sex relations join the queue of other religions and cultures, albeit in last position! (see Gerber, JJ and Du Toit, BJ 2006. Nederduitse Gereformeerde Kerk, Voorlegging aan die Porefeulje-Komitee van die Departement van Binnelandse Sake oor die Wysiging van die Huwelikswet (Wet No. 25 van 1961): reaksie op die Konsepwet vir Burgerlike Verbintenisse (Civil Unions Bill) - 3 October 2006. (Pretoria: Nederduitse Gereformeerde Kerk). Online: www.ngkerk.org.za

19 See Nederduitse Gereformeerde Kerk, Agenda Deel I -2007: Mediavrystelling: Die NG Kerk en die Voorgestelde Huwelikswet/Wet op Siviele Verbintenisse - 18 October 2006, at 2.3.8.*1; also Agenda Deel I2007: Verklaring van die Moderatuur van die NG Kerk oor Misverstande ten opsigte van die Voorlegging aan die Parlementêre Portefeulje Komitee Rakende Wetgewing oor Huwelike en Burgerlike Verbintenisse - 27 October 2006, at 2.3.8.*2; see also the letter by Burger, C at 2.3.9, and the accompanying letter written by Du Toit, B and Gerber, K 2006. Nederduitse Gereformeerde Kerk, Begeleidende Brief met Voorlegging oor Huwelikswet (spesifiek die Wetsontwerp of Burgerlike Verbintenisse). Online: http://www.ngkerk.org.za/Mediaverklaring.asp?pid=23\&sinid=22 - cited 17 April 2007.

20 See Nederduitse Gereformeerde Kerk, Agenda Deel I:Bylaag 1. Homoseksualiteit - 2007 at 3.4. 
protecting its continuity and maintaining a marginalised position for same-sex discourse. Marriage remains an exclusive heterosexual domain; as a matter of fact, it is in addition quite explicitly formulated that homosexual relationships and marriages cannot be accepted as alternative for marriage; if access to the office of minister is sought by a gay person, celibacy is mandated ... and that despite all the discursive practices in the generation of knowledge concerning same-sex relationships, humanity's sexuality is still divided into hetero- and homosexuals!

\section{How Biblical Discourse functioned in the Protection of the Dominant Discourse}

Foucault has indicated that in every society and community primary narratives are in circulation that function as documents or symbols of power. These narratives do not simply function as sources of information, as the substantiatory basis for arguments and conduct they are far more powerful than that, because they exhibit a productive force. As normative they function catalystically as part of regulatory practices, regulating and governing the products of their produce. Productively functioning as part of regulatory practices these narratives function in the making and regulating of bodies in communities. If power comes into existence by virtue of the repetitive act, each and every instantiation of these writings allows for an increase in their power. Whichever or whatever interpretation is given to these primary narratives it is not as forceful as the act of its citation, because in the act of citation lies what Foucault has called the 'dream of masked repetition.' According to him the 'topheaviness of the original text' allows for an ad infinitum creation of discourses and therefore also allows to say something which the original text has not really said; yet what is said in citational mode, whether that be commentary, reference, quotation, can only be said "on condition that it is the text itself which is uttered, uttered and in some ways, finalised" (1972 [1971]:221).

Like a refrain, the reformed tradition insists on the citation of Scriptures in the problematisation of gay relationships in the church. In nearly every official document of the reformed tradition, whether that be Acts of their synods, or official policy statements addressed to either Government or public, whether that be their official journals or official reports or meetings by enquiring subcommittees, one or the other reference, in differing degrees, are made to biblical discourse, its representation in terms of truth and knowledge. ${ }^{21}$ But the same applies to unofficial correspondence, such as private and public letters,

21 Just two examples: In the presentation of a reaction on the draft act for the Civil Unions Bill the Reformed Churches in Southern Africa issued a statement addressed to Ms Chohan-Kota and Mr Chauke respectively chair of the Portfolio Committee on Justice and Constitutional Development and of Portfolio Committee on Home Affairs, the very first statement reads: "According to Scriptures homosexual behaviour is against the order of creation (contra naturam)." And then in an argument from authority, Scriptures is then immediately deified with "God instituted the heterosexual monogamous marriage as the space within which sexuality must take place" (my translation; see Gereformeerde Kerke in Suid-Afrika: Voorlegging aan die PortefeuljeKomitee van die Departement van Binnelandse Sake oor die wysiging van die Huwelikswet (Wet no. 25 van 1961): reaksie op die Konsepwet vir Burgerlike Verbintenisse - 2006. Brief van Skriba Deputate vir gesprek met die owerheid (Dr N Vorster). Potchefstroom: Gereformeerde Kerke in Suid-Afrika. Online:

http://www.gksa.org.za/aktueel/brief\%20regering.asp -in a similar, yet more explanatory manner the DRC sketches to representatives of the Department of Internal Affairs how the Bible functions as 'guideline' for denominational activities and how same-sex relations are studied in 'light of Scriptures' and how legislation should allow room for the use of canonical documents (see Nederduitse Gereformeerde Kerk, Voorlegging aan die Portefeulje-Komitee van die Departement van Binnelandse Sake oor die wysiging van die

Huwelikswet (Wet no. 25 van 1961): Reaksie op die Konsepwet vir Burgerlike Verbintenisse - 3 Oktober 2006. Brief van Algemene Sekretaris (Dr JJ Gerber) en Parlementêre Lessenaar (Dr BJ du Toit). Pretoria: Nederduitse Gereformeerde Kerk. Online: http://www.ngkerk.org.za 
statements, seminars et cetera. ${ }^{22}$ Same-sex relations are made into a problem of truth, in which biblical discourse must function normatively in regulatory practice, more specifically, biblical discourse occupies the position of a point of alignment, regulating the degree of continuity and thereby also drawing a line between 'inside' and 'outside.' The higher the degree of continuity between Bible and commentary can be argued, the more authoritative the viewpoint becomes.

For that reason it becomes the reservoir of truths, the source containing some kind of concealed mysterious knowledge that has to inform denominational policy. It is the archive of reformed tradition and the fundamental assumption is its oracular capacity which has to be recovered. And the process of obtaining this mysterious knowledge is that of painstaking excavation and recovery, a never-ending search for an ever-hidden piece of wisdom, supposedly to be found at the origins of the texts, even beyond the origins at the feet of the original source. Foucault writes that it is this assumed stability, this enduring permanence of the primary text which lends it its capacity to be always updated, to be credited with multiple and hidden meanings, to be a reservoir of wealth from which the treasures have to be recovered and which ultimately 'creates an open possibility for discussion' (1972 [1971]:221). The search for the recovery of concealed wisdom does not have an end, there is no object to be found except to discover for the first time what has already been discovered. ${ }^{23}$ It is in this constantly repeated excavational act where power is produced and where the principle of hierarchy is time and again activated lending canonical status to the act of citation.

There is of course, no search, no recovery, no discovery - only a covering-up of our own political agendas and strategies, a process of appropriation for self-empowerment. The process of excavation, which biblical scholars would call 'exegesis,' takes place with a lexicon of our own design; the archaeological tools we use were not only manufactured in modern factories, but are technological extensions of our bodies, embedded and formed by contemporary culture. We avail ourselves of the discursive repertoire we currently have available, and so, we see what we have been trained or brainwashed to see; we quite often destroy what we have not been trained to see or even what we do not want to see. ${ }^{24}$ The 'findings' we thus produce quite often resemble exactly what we knew we would find. However, the 'search,' the excavational process, the exegesis in itself, allowed for the emergence of power, irrespective of what has been found. It is in the repetitive act of interpretation of the primary text, of commenting on the canonical document, that power generates discourse making and structuring the realities we occupy. As such the primary text and commentary in continuation with the primary text become a regulatory mechanism for the structuring of society.

Biblical discourse is both product of power and part of regulatory practice governing the bodies it produces. When biblical discourse is seen to function as part of regulatory practice the constant insistence on 'profound,' 'serious' and 'responsible' readings, interpretations or exegesis of the Bible becomes clear. It becomes clear why task teams or committees, study groups, experts, a continuous flow of interpreters have to be part of a never-ending

22 See for example the Conference held by the NG Gemeente Skuilkrans Pretoria, Homoseksualiteit: Wat sê ons vir mekaar? - 19 September 2002. Program. Pretoria: Nederduitse Gereformeerde Kerk. Online:

http://www.ngkerk.org.za/homoseksualiteit.htm, specifically the paper by André Bartlett, "Homoseksualiteit: wat sê ... Die Bybel".

${ }^{23}$ Foucault formulates: "It [the commentary's role] must ... say, for the first time, what has already been said, and repeat tirelessly what was, nevertheless, never said" (:221).

24 See for example Arondekar (2005) who shows how the colonial archive, accessed by colonial methodologies, perpetuates itself in the production of a colonial historiography on sexuality. 
enquiry into Scriptures. It is not any 'discovery' which is the objective, it is not any mysterious, hidden meaning residing in Scriptures, but it is what Scriptures does which makes it indispensable in regulating the bodies of its own productive power. For that reason, the power of Scriptures lies in the continuous act of interpretation and of providing commentary. This can and indeed will provide ad infinitum with new insights that have already been in circulation. The appeal to Scriptures has become like a ritual of which the original meaning has long ago been lost. Several meanings may be assigned to it, a variety of interpretations may be given and its origin may be clarified from different perspectives, but these recede and even disappear in the shadows cast by its performative power. And although appeal may be made to universal meaning residing in the bodily contortions exacted by the ritual performance, it functions to consolidate the in-group, to demarcate space and erect boundaries between 'outsiders' and 'insiders'. Denominations in the reformed tradition in South Africa fail miserably in the recognition of the performativity of the biblical discourse and therefore also of recognising their own political agendas in addressing contemporary issues.

A few examples should suffice. The politics of interpretation can be seen in the usurpation of biblical discourse by the parties concerned. In the two-pronged report by the Task Team of the DRC on 'homosexuality' the use of Scriptures as point of departure is stated as a matter of consensus. But it is in referring to the difference where its similar regulatory force, its power to perform demarcation, to effect a boundary is exhibited. Both reports make biblical discourse part of regulatory practice for the control of human bodies. In a similar manner do these reports exhibit a polemical politics of interpretation. In Addendum 1 a middle position, between a very broadly demarcated 'Fundamentalism' and 'Liberalism' is assumed, suggesting the desirable, necessary and sought-after value of 'balancedness' which is to reflect the objective position of their stance. It positions itself also against the so-called 'Hermeneutics of Enlightenment,' claiming their own position as a continuation of the accepted reformed tradition where a distinction between 'core' and 'periphery' is made. Yet any qualified biblical scholar would today deny the existence of a 'core', even in the separate writings of the Bible, not to speak of the Bible as a totality and would actually be a bit embarrassed to have Calvyn, Bavinck or Heyns (or for that matter De Gruchy) dictate the modus of the interpretative act. The point is that this group (which is the more enlightened of the Task Team) is less interested in the 'what' the Bible said, than the 'THAT' the Bible says, less interested in all the disruptions and discontinuities of history, than in demonstrating a continuity with what they regard as the acceptable and mainstream reformed tradition. It is then also not surprising that although ample room is created for same-sex relations within the hierarchies of this denomination, marriage for a gay couple is still excluded, albeit moderately formulated. ${ }^{25}$ The second report which served before the General Synod of 2007, reflected in Addendum 2, can indeed be seen as a form of Fundamentalism, ${ }^{26}$ and yet the reformed tradition is here also seen as its point of

25 This report is in favour of a relational institution in iuxtaposition to marriage which should then be called a 'homosexual life-relationship' - one can actually only stand amazed at the ignorance that renders (after so much enquiry!) constructed sexuality the pivot-point, the criterion of a relationship (see Nederduitse Gereformeerde Kerk, Agenda Deel I, 157 - bylaag 1, 3.4).

26 Without explicitly formulating, this group also positions themselves in a middle position between Postmodernism on the one hand, and lo'behold Fundamentalism on the other hand. In their explanation of Fundamentalism its critique actually consists of a summarising paragraph which in fact only reflects the perspective of the group itself. For an explanation of Fundamentalism see Vorster 1988, 155-175; this report also adheres to the principle of making a distinction between 'core' and 'periphery', and finds sexuality to be one of the 'cores' of biblical discourse which then also in toto condemns 'homosexuality' (see Agenda Deel I, $176-2,3.5 ; 200-2,4.2 .3 ; 203,2,5.1)$ 
departure. ${ }^{27}$ However, in this report there is no cloudy, nebulous distinction between true and false. Not only is 'commentary' here absorbed in discourse claiming absolute power actually suprahuman power, thereby excluding the possibility of critique and dissent, but the distinction between truth and falsehood also functions here as exclusionary procedure. As a matter of fact, any approach to Scriptures allowing for multiple interpretational possibilities is seen to devalue the authority of Scriptures. ${ }^{28}$ Biblical discourse occupies the highest pinnacle in the hierarchy of knowledge production, and functions as the criterion of truth even in the interaction with the natural sciences. ${ }^{29}$ It has become part of a regulatory practice determining what counts as knowledge, what counts as truth, what counts as discourse in which bodies may be embedded, but having 'become part of a regulatory practice' means that it is has already become the product of mechanisms and relations of power, as can amply be seen by its elevation to the level of canonicity.

Other examples of how biblical discourse is integrated into the power-politics of regulatory practice can be seen in its uses of the notions of 'homosexuality' and 'marriage.' In the widely, publicly advertised excavational expedition launched to deal with the emergence of gay-rights, whether that be membership, the right to ministry or marriage, the objective of this reformed tradition is to find or recover biblical evidence of 'homosexuality' and biblical advice on how to deal with it. This, at least is the claim made by all groups intent on finding the solution. Once again, it is neither a matter of understanding Scriptures, nor of humanity embedded in its historical contingencies, but rather a conscription of the performative power of biblical discourse with the objective to demarcate and regulate spaces for bodily occupation. The search for 'homosexuality' in antiquity where the Bible incidentally originated, is a search in vain, because 'homosexuality' is a socially constructed form of sexuality that emerged in the late nineteenth century. The Task Team of the DRC is quite aware of this debate among classicists and gender critics, ${ }^{30}$ but it is completely underplayed in the reports itself, use being made of it, only where it fits the specific interest of a viewpoint, and yet their 'findings' are presented as if this was the object of scriptural study! The almost arrogant assumption is that our contemporary experiences, completely differently manufactured ${ }^{31}$ must have been the same as those of the ancient Mediterranean world, that the Bible must have the capacity, a hidden mysterious power to address modern society, that a linear continuity with biblical material can be established. The basic problem is a refusal to acknowledge the socio-cultural constructedness of sexuality. It is true that there is not wholesale consensus among classical and gender critical scholars whether 'homosexuality' can be recovered in antiquity or not. However, since Foucault's groundbreaking study on the History of Sexuality, enquiries into human sexuality can no longer assume a trans-historical and -cultural approach. ${ }^{32}$ For that very

27 See Nederduitse Gereformeerde Kerk, Agenda Deel I, 173 - bylaag 2, 3.2.

28 Nederduitse Gereformeerde Kerk, Agenda Deel I, 165 - bylaag 2, 1.2.1; also 201 - 2, 4.2.4.

29 See for example: more cautiously formulated that the church should also listen to medical research, although the Bible remains the 'highest source of truth' in reflecting on the relationship between God and neighbour, but also when it concerns sexual relationships (Nederduitse Gereformeerde Kerk, Agenda Deel I, 173 - bylaag 2, 3.1.), but then more boldly in an almost Galileo-argument: "even if science were to prove incontestably that someone is born homosexual, a scientific given cannot veto a theological concept (such as sin)." (Agenda Deel I, 169 - bylaag 2, 1.7.3, my translation and italics).

30 See for example Nederduitse Gereformeerde Kerk, Agenda Deel I, 188 - bylaag 2, 4.2.2; also Agenda Deel I, 190 - bylaag 2, 4.2.2.3; also Agenda I, 194 - bylaag 2, 4.2.2.4b.

31 See for example Halperin 1998, 96

32 See Foucault 1978, 36-49, 122-127; Halperin 1990, 15-18, 155; for an indication of the problems early Christianity struggled with in terms of sexuality see also Foucault 1997 [1981], 182; Karras 2000, 1251-1257; Boyarin \& Castelli 2001; Vorster 2005, 754-760. 
reason, even though the term 'homosexuality' is used as a category for analysis in some instances, the conditions constituting sexuality, also same-sex in antiquity are completely different from contemporary society. ${ }^{33}$

That the concern is the act of integrating biblical discourse as performative power in regulatory practice can be seen in the ambiguous use of the social constructivist perspective on homosexuality in the second addendum of the DRC's Task Team. To regulate 'homosexuality' via biblical discourse, it is vital to discover the same 'homosexuality' in antiquity. Those classicists and gender critics, cautious of what can be termed 'strong' or radical social constructivism, ${ }^{34}$ are usually inclined to minimise the differences between then and now. 'Homosexuality' would still be a socio-cultural construct, but the degree of difference is disputable according to the weaker version. When socio-cultural constructivism is rejected, a more naturalistic or even essentialistic approach can easily discover exactly the same 'homosexuality' in antiquity. In an attempt at what can be called 'homosexual apologetics' the latter viewpoint becomes quite handy when used in conjunction with the recent quest for a biological aetiology which could explain the phenomenon of homosexuality. If this possibility were to become reality, its 'naturality' would obviously make it more difficult for those who wish to regulate what was regarded as 'abnormal' and 'unnatural.' However, if contemporary 'homosexuality' is indeed a socio-cultural construct, then it is quite possible that a culture adhering to a 'one-sex model,' with the phallus as primary cultural signifier and a manhood identified with impenetrability, could have constructed its sexualities in a completely different manner.

To walk the road of socio-cultural constructivism is to admit to difference. But this constitutes a problem for those who wish to integrate a continuity with biblical discourse in a regulatory practice demarcating a specific place for those in same-sex relationships. So what does the Task Team of the DRC do? To establish a continuity between 'homosexuality' then and 'homosexuality' now, and to fend them off against those colleagues discovering in biblical material only references to perverted forms of homosexuality, while at the same time casting doubt on a similar phenomenon, the 'experts' inclining towards a more naturalistic, essentialistic or even weaker form of constructivism are summoned to witness in favour of similarity. ${ }^{35}$ But then, when a defence has to be lodged against the quest for a biological aetiology for homosexuality, the most radical version of sociocultural constructivism is adhered to, namely Michel Foucault and his disciple David Halperin. ${ }^{36}$ The problem is, however, that if the latter viewpoint is adhered to, a completely different set of discursive practices constituted same-sex relationships in antiquity, requiring that the differences be recognised and discontinuity be established.

33 See Laquer 1990; Parker 1997. Amy Richlin (1993), who can be seen as anti-Foucault, illustrates the difficulties involved in understanding a category, such as the cinaedus who was indeed mentioned and referred to in antiquity.

34 For this division in 'stronger' versus 'weaker' see Thorp 1992, 56.

35 See the references to Boswell, Dover, and Hubbard at Nederduitse Gereformeerde Kerk Agenda Deel I, 188 bylaag 2, 4.2.2; 190 - bylaag 2, 4.2.2.3, 194 - bylaag 2, 4.2.2.4b. In each of these cases the reader is assured of their expertise, either by reference to them as 'scholars' (geleerdes) or 'classical historians' (klassieke historici) or even by direct reference to reliability as is the case with Boswell who is depicted as a 'history professor at Yale University' (geskiedenisprofessor aan Yale-universiteit).

36 It is quite ironic that on the same page where reference is made to Foucault and Halperin a little window reads: "In the quest for a scriptural justification of homosexual relationships and marriages, science is used like political slogans - depending on which side of the debate one finds oneself, only those supposed findings are used" (my translation) - see Agenda Deel I, 214 - bylaag 2, 8.3. 


\section{Conclusion}

The development of same-sex discourse in the reformed tradition, in particular in the DRC, served performatively. There was, and is little interest in the interest of same-sex relationships. By the proliferation of public discursive practices, especially since 2002, it forced same-sex relations out of the closet into the arena. What can essentially be seen as a private, consensual act between adult persons, albeit from the same sex, has been transferred from the cubiculum (bedroom) to the spectaculum (spectacle). As the 'orientations' of bodily interiority were shoved into the arena, scrutinised and analysed, the crowd clamoured for judgements, decisions and final convictions. The movement out of closet concealment, allowed, at the same time, the demarcation of space where same-sex desires and practices remain confined to be examined and controlled. The allocation of demarcated space is no emancipation, but a dispossession, a forced removal, a placement in the space of heteronormativity. It serves to protect and continue traditional reformed discourse, but it allows little breathing space for a gay person. But this placement also effects a productive force, it makes an identity. To be gay in the DRC means to be constantly aware of your own alterity; ousted from entering 'marriage' your so-called sexual orientation qualifies your lifelong partnership with your partner as 'homosexual'; your 'inability' to enter marriage, will also disqualify you to enter the ministry, except via a denial of your sexuality.

We have seen that biblical discourse was integrated into regulatory practice, serving as a mechanism to protect from alternative discourse and at the same time continue heteronormativity. The constant appeal to Scriptures brought no relief for same-sex relationships but served to replicate hegemonic control, even among those circles where freedom for gays were sought. The function of the appeal to Scriptures in the DRC has little concern with understanding, with 'light,' but much with power. Instead of looking upon Scriptures as a reservoir of wisdom, its performative possibilities should be recognised and problematised. The Bible will not provide the solution to what some regard as a problem - on the contrary, the Bible is part of the problem.

Is a conversation still possible where we may use the same vocabularies and terminologies, but do different things with them? Is a rhetoric possible where so much discursive violence can be detected? The rhetoric which is possible, is a rhetoric of dissent; it is a rhetoric which should reverse the feigned quest for original biblical meaning; it is a rhetoric which should bring about a recognition of the demarcating, delineating, isolating act of regulatory practice and primary narrative ... and it is a rhetoric which should not only bring about a recognition of the immense disruptions and discontinuities between antitquity and ourselves, but also work towards the discontinuation of discursive securities violently imposed on the flow of life. ${ }^{37}$

37 For the principles of reversal, discontinuity, specificity and exteriority see Foucault 1972 [1971]: 229. 


\section{BIBLIOGRAPHY}

Arondekar, A 2005. Without a Trace: Sexuality and the Colonial Archive. Journal of the History of Sexuality 14(1/2):10-27.

Benadé, L 1999 (December). Gay-wees nie ál wat Bybel verbied. Die Kerkbode 163(16).

Botha, A 1999 (November). Gemeentes wil oor gays praat. Die Kerkbode 163(13).

Boyarin, D and Castelli, EA 2001. Introduction: Foucault's History of Sexuality: The Fourth Volume, or, A Field left Fallow for Others to Till. Journal of the History of Sexuality 10(3/4):357-374.

Burke, K 1969. A Rhetoric of Motives. Berkeley: California University Press.

De Villiers, E 1999 (November). 'Prosedure' pootjie debat oor homo's. Die Kerkbode 163(11).

Die Kerkraad, 1999 (November). Wat sê die Here oor homoseksualiteit. Die Kerkbode 163(13).

Foucault, M 1972 [1971]. The Discourse on Language. Pages 215-237. In M Foucault, The Archaeology of Knowledge. Translated by AM Sheridan Smith. New York: Pantheon Books.

Foucault, M 1978. The History of Sexuality. Vol 1. An Introduction. Translated by R Hurley. London: Penguin Books.

Foucault, M 1997 [1981]. Sexuality and Solitude. Pages 175-184 in Michel Foucault: Essential Works of Foucault 1954-1984. Vol 1. Ethics: Subjectivity and Truth. Translated by R Hurley and others. New York: The New Press.

Gerber, K 2004. Nederduitse Gereformeerde Kerk, Persvrystelling: Hofuitspraak oor gay huwelike. Online: http://www.ngkerk.org.za/Hofuitspraak\%20Gayhuwelike\%Pers.htm

Gerber, JJ and Du Toit, BJ 2006. Nederduitse Gereformeerde Kerk, Voorlegging aan die Porefeulje-komitee van die Departement van Binnelandse Sake oor die wysiging van die Huwelikswet (Wet No. 25 van 1961): reaksie op die Konsepwet vir Burgerlike Verbintenisse (Civil Unions Bill) - 3 October 2006, 1-7. Pretoria: Nederduitse Gereformeerde Kerk. Online: www.ngkerk.org.za

Gereformeerde Kerke in Suid-Afrika: Voorlegging aan die Portefeulje-komitee van die Departement van Binnelandse Sake oor die wysiging van die Huwelikswet (Wet no. 25 van 1961): reaksie op die konsepwet vir burgerlike verbintenisse - 2006. Brief van Skriba Deputate vir gesprek met die owerheid (Dr N Vorster). Potchefstroom: Gereformeerde Kerke in Suid-Afrika. Online: http://www.gksa.org.za/aktueel/brief\%20regering.asp

Geloofsverklaring 2000, 1999 (July). Die Kerkbode 163(7).

Halperin, DM 1990. One Hundred Years of Homosexuality: And Other Essays on Greek Love. London: Routledge.

Halperin, DM 1998. Forgetting Foucault: Acts, Identities, and the History of Sexuality. Representations 63:93-120.

Janse van Rensburg, R 1999 (September). Wat God van homoseksualiteit dink... Die Kerkbode 163(8).

Karras, RM 2000. Active/Passive, Actions/Passions: Greek and Roman Sexualities. American Historical Review 105(4):1250-1256.

Kloppers, BJ 1999 (November). Homo's laat gesin uit NG Kerk loop. Die Kerkbode $163(11)$. 
Laquer, T 1990. Making Sex: Body and Gender from the Greeks to Freud. Cambridge: Harvard University Press.

Lidmate verskil skerp oor homo-verslag 1999 (September) Die Kerkbode 163(6).

Luyt, C 1999 (October). Nie weer na te dink oor homoseks. Die Kerkbode 163, no 9.

Mills, S 2003. Michel Foucault. London: Routledge.

Nederduitse Gereformeerde Kerk, Besluite van die Algemene Sinode 1986. Aanbevelings van die kommissie vir Leer en Aktuele Sake, 363. Pretoria: Nederduitse Gereformeerde Kerk, 1986.

Nederduitse Gereformeerde Kerk, Agenda van die Wes- en Suid-Kaap Sinode 1999: Bylae A13-1 van die Verslag van die Kommissie vir Leer en Aktuele Sake van Wes- en Suid-Kaap aan die Sinode 1999. Pretoria: Nederduitse Gereformeerde Kerk.

Nederduitse Gereformeerde Kerk, Agenda, Notule en Besluiteregister van die Algemene Sinode van die Nederduitse Gereformeerde Kerk - 2002, 246-254; 554; 624. Pretoria: Nederduitse Gereformeerde Kerk, 2002. ABID, cited 30 July 2008, 1-16.

Nederduitse Gereformeerde Kerk, Agenda, Kronologiese en Inhoudelike Notule van die Algemene Sinode van die Nederduitse Gereformeerde Kerk - 2004, 138-151; 328329; 374. Pretoria: Nederduitse Gereformeerde Kerk, 2004. ABID, cited 30 July 2008, 1-17.

Nederduitse Gereformeerde Kerk, Agenda Deel I: Dokumentebundel vir die 13de Vergadering van die Algemene Sinode van die Nederduitse Gereformeerde Kerk, Boksburg 4-7 Junie 2007. Verslag van Taakspan: Homoseksualiteit. Pretoria: Nederduitse Gereformeerde Kerk, 2007. Cited 3 November 2008. Online: http://www.ngkerk.org.za/documents/Agenda2007Deel1.pdf

Parker, HN 1997. The Teratogenic Grid. Pages 47-65 in Roman Sexualities. Edited by Hallett, JP \& Skinner MB. Princeton: Princeton University Press.

Richlin, A 1993. Not before Homosexuality: The Materiality of the Cinaedus and the Roman Law against Love between Men. Journal of the History of Sexuality 3(4):523-573.

Peters, JD and Rothenbuhler, EW 1989. The Reality of Construction. Pages 11-24 in The Rhetoric in the Human Sciences. Edited by HW Simons. London: Sage.

Thorp, J 1992. Review: The Social Construction of Homosexuality. Phoenix 46(1):54-61.

Viljoen, WJ 1999 (September). Homo's misbruik hulle seksualiteit, Die Kerkbode 163, no. 8.

Vorster, JN 1988. The Use of Scripture in Fundamentalism. Pages 155-175 in Paradigms and Progress in Theology. Edited by Mouton, J, Van Aarde, AG and Vorster, WS. Pretoria: Human Sciences Research Council.

Vorster, JN 2005. The Rhetoric of Graeco-Roman Erotic Love versus Early Christian Rhetoric. Scriptura 90(3):740-764.

Wessels, F 1999 (September). Vet in vuur oor homoseksualiteit. Die Kerkbode 163(7).

Wes-Tvl verander besluit oor homoseksualiteit 1999 (September). Die Kerkbode 163(8). 